\title{
IPLOMACY AS A LIFESTYLE. NORDIC
AND RUSSIAN DIPLOMATS AS LINKS
BETWEEN THEIR COUNTRIES AND \\ THE ROMANIAN AREA (17TH - 19TH CENTURIES)
}

\section{Mihaela Mehedinți}

Babeş-Bolyai University, Cluj-Napoca, E-mail: mihaela_mehedinti@yahoo.com

\section{Acknowledgments}

This paper has been presented at the Fourth International Conference on Nordic and Baltic Studies „Empire-building and Region-building in the Baltic, North and Black Sea Areas", in Constanta, Romania, May 24-26, 2013.

\begin{abstract}
:
Building large political structures was always closely connected with a fragile balance between military conflicts and peace. Thus, especially in the modern period, diplomats played an extremely important role in managing crisis situations and/or maintaining the status quo. Moreover, they represented the most visible facet of interstate relationships.

During the 17th - 19th centuries, Europe's tumultuous history, characterised by frequent wars, many of which against the Ottoman Empire, gave the diplomats' services an inestimable value. In this context, Transylvania, Moldavia and Wallachia usually represented only intermediary points on the route towards the diplomats' final destination, namely the Turks' Empire.

The present study aims at revealing the multiple forms of interaction between the Nordic (chiefly Swedish) and Russian diplomats, on the one hand, and the Romanian rulers, on the other hand. In order to achieve this goal, general historical information was intertwined with numerous testimonies pertaining to this special category of foreign travellers, the result being a picturesque depiction of certain typicalities of the diplomatic ceremonial.
\end{abstract}

\section{Rezumat:}

Realizarea de structuri politice mari a fost întotdeauna strâns legată de un echilibru fragil între conflictele militare și pace. Astfel, mai ales în perioada modernă, diplomații au jucat un rol extrem de important în gestionarea situațiilor de criză și 
/ sau menținerea status quo-ului. Mai mult decât atât, ei au reprezentat fațeta cea mai vizibilă a relațiilor interstatale.

Pe parcursul secolelor al XVII-lea - al XIX-lea, istoria tumultoasă a Europei, caracterizată prin războaie frecvente, dintre care multe impotriva Imperiului Otoman, a conferit serviciilor făcute de diplomați o valoare inestimabilă. In acest context, Transilvania, Moldova și Țara Românească au reprezentat, de obicei, doar puncte intermediare pe traseul spre destinația finală a diplomaților, și anume Imperiul Otoman.

Studiul de față iși propune să dezvăluie formele multiple de interacțiune dintre diplomații nordici (mai ales suedezi) și ruși, pe de o parte, și domnitorii români, pe de altă parte. Pentru a atinge acest obiectiv, informații generale de istorie au fost intercorelate cu numeroase mărturii referitoare la această categorie specială de călători străini, rezultatul fiind o descriere pitorească a anumitor tipicuri ale ceremonialului diplomatic.

Keywords: diplomacy, Nordic countries, Russia, Romanian Principalities, 17th-19th centuries

\section{Introduction}

Negotiations are a part of everyday life and this is an undeniable truth even if one takes into consideration past historical epochs. Daily interactions with other people have always implied certain types of behaviours: stating an opinion, bringing arguments in its favour, combating opposing views, reaching a conclusion. All these stages that comprise the majority of discussions, including the most innocent ones, become proportionately important when one considers the relations between two states. Thus, diplomats need to possess particular traits and therefore they are habitually chosen very carefully and their apprenticeship is closely monitored.

Due to their services' inestimable value, with time special rules regarding diplomats and their activity emerged. The treatment bestowed upon them by the states that were placed on the route towards their final destination and especially by the receiving country respected a set of rules that were generally meant to facilitate the emissaries' missions and alleviate some of the perils and hardships of their travels.

Such concerns and interests were particularly relevant during the 17th-19th centuries, when Europe was tormented by a number of political crises that ended in wars. This fragile balance between military conflicts and peace, this state of equilibrium that could only be maintained by resorting to diplomatic means is especially visible when referring to large political structures that found themselves either in decline or during a period of 
marked growth. Sweden and Russia could be placed somewhere in between these limits of the continuum and their status on the international scene varied during this rather large interval.

As intermediary points on the route to Constantinople, Transylvania, Moldavia and Wallachia obeyed the above-mentioned unwritten rules regarding the manner of treating the Nordic (mostly Swedish) and Russian envoys that were on their way towards meeting the Sultan. The interactions between these representatives and the Romanian rulers reveal numerous facets of politics during the modern period and combining the former's accounts with the available historical data ensures both a touch of originality for this study and a picturesque reading.

In order to maximise the potential of this important historical source, namely the narrations of the Nordic and Russian emissaries who passed through contemporary Romania in the specified period, the study begins by summarising the notes regarding the treatment granted by the Transylvanian, Moldavian and Wallachian rulers to the foreign delegates, but also those about other reciprocal benevolent attitudes and courteous gestures. But, these statements could not be properly analysed without placing them in context, and, as a result, the latter sections of the study present the epoch's diplomatic relations between the areas had in view (i.e. Transylvania and the Romanian Principalities, on the one hand, and the Nordic countries and Russia, on the other hand), before drawing a few general conclusions.

\section{The treatment bestowed upon the Nordic and Russian diplomats by the Romanian rulers}

As William Roosen emphasises, ceremonial refers to "the procedures, traditions, rights and hopes" involved in the interactions between the representatives of two states. ${ }^{1}$ As a result, the manner of receiving foreign diplomats offers valuable information concerning the relations between the powers involved in negotiations, the respect owed to the country that had sent its messengers to another state and/or the lesser or greater political role of the discussions.

The manner of receiving and the behaviour towards the delegates during their stay in the Romanian Principalities or in Transylvania thus represents one of the most trustworthy indicators of the quality of the rapports between these areas and their country of origin. Sometimes, the

\footnotetext{
1 William Roosen, "Early Modern Diplomatic Ceremonial: A Systems Approach," The Journal of Modern History, Vol. 52, no. 3 (1980): 452.
} 
emissaries did not consider themselves worthy of some treatments ${ }^{2}$ that the Romanian rulers deemed necessary either out of consideration for the former's sovereigns or simply in order to respect certain usages. The reception offered to Paul Strassburg by Leon Tomşa in 1632 belongs to the first of the two mentioned categories. The Wallachian ruler wanted to greet the diplomat in person at a certain distance from Bucharest but, as Nicolae Iorga puts it, such a welcome "was too heavy for the envoy's modesty". Nonetheless, Leon Tomşa sent a suite of 100 boyars to accompany the Swede and, when the latter entered the audience room, received him bareheaded. ${ }^{3}$ Furthermore, at the moment of the emissary's departure the Romanian hospodar displayed new signs of appreciation: the number of people escorting Strassburg was increased to "a thousand horsemen and six hundred infantrymen" (!) and music surrounded the entire group. ${ }^{4}$

The pastor Conrad Iacob Hiltebrandt also illustrates how the Swedish representatives were treated by the Romanian rulers in the $17^{\text {th }}$ century, but, this time, the protagonist was the Transylvanian prince George II Rákóczi. The envoys "were solemnly greeted by soldiers" near Cluj and, on the road towards the castle where the prince awaited them, they travelled in "a princely carriage, with the calash lowered" and pulled by " 6 beautiful horses". A series of Transylvanian noblemen were included in this retinue, alongside a few military men. The "sumptuous" clothing worn by George II Rákóczi and by his wife, Sofia Báthory, during the audience and the dinner that followed denoted as well the significance conferred on this event by them. Moreover, the fact that the foreigners were seated at the table next to the ruler, that they were served by a number of Hungarian noblemen and that they were using silver plates and goblets ${ }^{5}$ further emphasises that the Swedes' presence in Transylvania was considered a special occasion, all

\footnotetext{
${ }^{2}$ Mihaela Grancea also remarks that a number of the travellers are "flattered by the etiquette and courteousness [encountered] at the rulers' residences". For more details, see Mihaela Grancea, Călători străini prin Principatele Dunărene, Transilvania şi Banat (1683-1789). Identitate şi alteritate (Sibiu: Editura Universității „Lucian Blaga”, 2002), 97.

${ }^{3}$ Nicolae Iorga, Istoria românilor prin călători (Bucharest: Eminescu, 1981), 210.

${ }^{4}$ Moreover, "in order to increase the pomp, in front of the retinue there was placed a redcoloured flag of an unusual size that had been sent by the ruler's Sultan, as well as other flags of Wallachia. / The trumpets and drums resounded in the nearby woods and in the neighbouring forest. / On both sides the country's officials and boyars advanced, riding Asian horses and adorned with shiny clothes. / Near the ruler there were the fiddlers and a choir of musicians who sung fierily an old ballad in the Romanian language". The quote was taken from Maria Holban, M. M. Alexandrescu-Dersca Bulgaru and Paul Cernovodeanu, eds., Călători străini despre Țările Române, Vol. V, (Bucharest: Editura Ştiințifică, 1973), 65 (hereinafter: Călători străini..., Vol. V).

5 Ibid., 557-558.

148
} 
these ceremonial elements actually illustrating the glory and honour ${ }^{6}$ of Charles X Gustav, King of Sweden.

The display of other signs of appreciation continues, as before entering Alba Iulia, George II Rákóczi's residence, the Swedish delegates were greeted and accompanied to the house that they were going to occupy by a considerable number of military men. ${ }^{7}$ However, the accommodation provided is far from perfect ${ }^{8}$ and the manner in which they were served the various meals of the day ${ }^{9}$ comprised a series of hilarious elements (or at least details that were presented in such a way, intentionally or not):10 "we had a Hungarian chef who made a lot of noise and hubbub in the kitchen; every time you looked, you could see only onions that he cut in small pieces. The table was organised in the following manner: we had a few tin and some wooden 'talere' (plates) that the inhabitants were forced to procure, as well as a tablecloth and that was all; when the plates needed to be changed, Német Niclas's servant, Mihuc grabbed the gentlemen envoys' plates, threw the bones back over his head, wiped the plates a little either with his coat or with an old rag and presented them anew to the gentlemen. The foods were nevertheless worthy of praise and good, garnished and sprinkled with spices, as is customary in Hungary, so that because of this the sauce burnt

\footnotetext{
${ }^{6}$ It seems that these two traits were most frequently placed in connection with the various behaviours specific to diplomacy in the modern epoch, irrespective of the fact that the persons involved represented kings or republics. For details, see Roosen 1980, 457-458.

7 Călători străini..., Vol. V, 560.

8 "Our house was generally called the Turkish house, [and it was located] not far from the castle. It was organised in the following manner: a room that was decorated with gilded [animal] skins was assigned to the gentlemen envoys and next to it there was a small room; in the other room there was no window and it was exceedingly cold; we found no bedclothes except some empty wooden beds and a table. The gentlemen envoys had with them their travelling blankets, <but> the servicemen were forced to sleep on an armful of hay and half of their cloak and with the other half they covered themselves; the pillow for the head was the saddle". See Ibid., 561.

9 Some authors consider that it is possible to speak about a "national identity" that can be noticed while studying nutrition. Moreover, one could even argue that the publication of cookery books in the national languages during the 19th century has influenced to a certain degree the fight for independence of such states as Iceland, Norway or Finland, which can thus be placed alongside the Romanian area from this viewpoint, because the abovementioned books appeared in these four countries in 1800, 1831, 1834 and 1841, respectively. For other details concerning this topic, see Henry Notaker, "En contrepoint: L'identité nationale à travers les livres de cuisine du XIXe siècle," in Histoire et identités alimentaires en Europe, eds. Martin Bruegel and Bruno Laurioux (Paris: Hachette Littératures, 2002), 137-150. 10 More information regarding the importance of gastronomy in the case of diplomatic contacts can be found in Grancea 2002, 229-230.
} 
like a brandy the mouth and throat of the one who was eating them; as beverage the gentlemen envoys had a good wine".11

It seems that accompanying the diplomats that came to see the Moldavian ruler on a certain portion of their route was one of the most frequent usages of the $18^{\text {th }}$ century. An emissary that received this treatment was Edvard de Carleson, the representative of Frederick I of Sweden to Constantinople. The Moldavian boyar Dumitraşcu Paladi received the important task of greeting the Swedes at a particular distance from Jassy and of presenting an extremely courteous letter from John Mavrocordatos to his future guests. ${ }^{12}$ Paul Jamjouglou, the Swedish mission's interpreter, notes: "we saw arriving a numerous flock ${ }^{13}$ of well-organised horsemen who came to receive the Swedish envoy. They were gentlemen seneschals (ministers), the ruler's first sword bearer and many other high dignitaries of the court, the court's marshal, six ushers or masters of ceremonies, richly clothed in suits with golden threads, having in their hands their ceremonial silver batons, 300 mercenaries with their officers who formed some sort of a guard, three beautiful carriages that were each pulled by six horses, superbly harnessed. // When the entire retinue arrived at approximately a hundred steps from us, the gentlemen seneschals dismounted and came to salute the Swedish envoy in the Italian language, asking him to take a seat in the most beautiful of the carriages, that belonged to the ruler himself who used it with the occasion of the most important ceremonies"..$^{14}$

The importance granted to the Nordic deputation is obvious also from the fact that even Paul Jamjouglou was very well received by the ruler and his wife, the discussion with them lasting for over an hour, during which coffee was served "with all the solemn customs utilised on such occasions". 15 The friendly gestures towards Sweden's representatives continued: as it was customary in the period, they were given a series of precious gifts 16 and

\footnotetext{
11 Călători străini..., Vol. V, 561.

12 George Cristea, Regi şi diplomați suedezi în spațiul românesc (secolele XII-XX) (Cluj-Napoca: Academia Română, Centrul de Studii Transilvane, 2007), 138.

13 The fact that the political ceremonial implied a large group of people is considered one of the defining elements of the "state baroque" that characterised the European courts during the $17^{\text {th }}-18^{\text {th }}$ centuries. See Grancea 2002, 73.

14 Cristea 2007, 138.

15 Constantin I. Karadja, "Le journal de Paul Jamjouglou de Constantinople à Hotin en 1746," Revue Historique du Sud-Est Européen (1930): 29.

16 "We were also sent from the ruler's court over 40 silver vessels with jams of the best sorts, around 30 bottles with liqueur and another 30 silver vessels of the usual size with rose jam as well as two large coffeepots filled with coffee". These gifts are enumerated by both Cristea 2007, 139 and Karadja 1930, 29.
} 
Edvard de Carleson reciprocated by rewarding those who brought the respective presents.

A similar reception was offered to the Russian delegation which included Nikolai Vasilievici Repnin. He details the manner of welcoming foreign diplomats in Moldavia around the year 1775, his description illustrating that it was the authorities' desire that important people from the ruler's suite would accompany the emissaries towards the capital from a certain distance. Apparently, the attention given to the messengers increased as they approach Jassy and music, 17 the exchange of gifts, dining with the representatives and concern for the ladies ${ }^{18}$ were important parts of the ritual. 19

Another interesting piece of information is that during the official meeting at the Jassy court "at the table Moldavian music was played; after lunch Moldavian dances were danced and the ambassador played cards with the ruler", an activity that was repeated during the Russian diplomats' stay in the Moldavian capital. On the other hand, the notes regarding the fact that the emissary went hunting with the ruler ${ }^{20}$ are not so frequent. In order to please the Russian representative, Grigore Ghica even offers him a spectacle that included "different equestrian exercises, according to the Turkish and Moldavian custom. In the meantime, coffees, sweets and different cold beverages were brought. Towards the twilight dinner was served, at which all those present were fed. After dinner, the ruler's children

\footnotetext{
17 According to a number of 19th-century Romanian intellectuals such as Valeriu Branişte, music and dance represented defining elements of national identity, especially if we refer to folk music and dance. More particulars about this topic are provided by Sanda Luminița Ignat-Coman, "Identitatea națională în opera lui Valeriu Branişte," in Identitate şi alteritate: Studii de istorie politică şi culturală, Vol. 5, eds. Constantin Bărbulescu, Ioana Bonda, Cecilia Cârja, Ion Cârja and Ana Victoria Sima (Cluj-Napoca: Presa Universitară Clujeană, 2011), 289. 18 This care was illustrated by the fact that the ambassadors' wives were greeted and treated by the Moldavian rulers' consorts in a fashion that mirrored the relation between their husbands. For more details, see infra.

19 The detailed description pertaining to the aforementioned Russian representative is available in Maria Holban, Maria M. Alexandrescu-Dersca Bulgaru and Paul Cernovodeanu, eds., Călători străini despre Țările Române, Vol. X, part I (Bucharest: Editura Academiei Române, 2000), 197-199 (hereinafter: Călători stăini..., Vol. X, part I).

20 The presence of this particular element, as well as of folk dances, military exercises, fireworks or the habit of playing cards are considered to be signs of emancipation of the Moldavian diplomatic ceremonial in relation to the Ottoman one by Grancea 2002, 107. Neagu Djuvara also remarks that "although hunting seems to have been highly valued by some of the boyar families from Moldavia, the foreigners of note who come in the Romanian Principalities are often surprised to see how little it is practiced in Wallachia amongst the ruling class"; Neagu Djuvara, Între Orient şi Occident. Țările române la începutul epocii moderne (1800-1848) (Bucharest: Humanitas, 2005), 131.
} 
and his courtiers amused the guests with national dances. At the end, a little fireworks display was shot from the foot of the hill. After this, the prince mounted and left for his residence, where he was accompanied by the ruler himself". ${ }^{21}$

Two decades later, in 1793, the Russian general Mihail Kutuzov enjoys approximately the same treatment, but this time its provider was Mihail Şuț. According to the account of Johann Christian von Struve, a member of this delegation, the Russians were greeted by the Moldavian ruler in person and he was "coming in a beautiful carriage pulled by six horses, surrounded by his guard, his court and the country's army, in order to welcome our envoy, whom he accompanied to Jassy, where all the windows were like a sea of heads and the houses' roofs were filled with people. In the house that was destined for lodging the deputation, a large and brilliant feast awaited us. The ruler ate with us. He seated himself together with our envoy at the head of the table, which was occupied on the right [side] by the court of the Moldavian ruler and on the left [side] by us and the persons from the deputation. Towards the evening, we were brought a music that was quite similar to the Turkish music ${ }^{22}$ and then everyone retired in order to throw themselves into the arms of sleep and to rest after the fatigue of such a noisy day". ${ }^{23}$

The ruler's high regard for the Russians is proven, amongst other things, by the fact that they were seated on his left-hand side, which represented the place of honour for the Ottomans ${ }^{24}$ (and, thus, in the Romanian Principalities as well), but also by the care with which he occupied the emissaries' time with a series of entertainments and visits. ${ }^{25}$ In addition, as Heinrich von Reimers, another member of Kutuzov's deputation, reports,

${ }^{21}$ Călători străini..., Vol. X, part I, 200.

22 Details about the ceremonial Ottoman music (mehterhanea) and its presence at the ruling courts of the Romanian Principalities are provided by Claudiu Neagoe, "Veşminte, muzici şi imagini în T,ara Românească (secolele XVI-XVIII)," in De la fictiv la real. Imaginea, imaginarul, imagologia, eds. Andi Mihalache and Silvia Marin-Barutcieff (Jassy: Editura Universității „Alexandru Ioan Cuza”, 2010), 531-533.

${ }_{23}$ Maria Holban, Maria M. Alexandrescu-Dersca Bulgaru and Paul Cernovodeanu, eds., Călători străini despre T,ările Române, Vol. X, part II (Bucharest: Editura Academiei Române, 2001), 1,126 (hereinafter: Călători străini..., Vol. X, part II). The same ceremonial, with some small variations related to the persons present, is also described by von Struve a year later, when Kutuzov's deputation returned to Russia.

24 Roosen 1980, 466.

25 Johann Christian von Struve notes: "We have spent 14 days here [in Jassy], during which time the ruler has strived in every way [possible] to amuse and delight his guests. Each day had its distinct celebration and the few moments that remained, after all sorts of parties, were used for visiting the town's curiosities, as well as its surroundings and the ruler gave us for this purpose all the facilitations that could be imagined"; Călători străini..., Vol. X, part II, 1126. 152 
when the envoy arrived at the palace to meet with the hospodar, "the bells started to ring and two cannons were fired - the only cannons of Jassy, as I was told". And, as proof that this friendliness was mutual, the ambassador "was riding the horse that had been given to him by the ruler before noon, with the occasion of the welcome meeting. When he dismounted, the (Albanian) hiremen fired several salvoes and, at the palace's entrance, the ruler received him". 26

The departure of the emissary and his suite took place with the same pomp and they enjoyed "a very pleasant surprise when, upon arriving at Galata, a monastery placed on a height, we encountered here entirely unexpectedly a morning meal richly and brilliantly served that the ruler had ordered to be prepared for us. Four large tables, loaded with all sorts of foreign wines, with the most select fruits, with sweets and other dainties, were laid underneath beautiful tents, adorned with garlands of flowers and foliage and with all kinds of ribbons". And it seems that the effect of this regale was the one hoped-for, as "we were not too ceremonious and we speedily seated ourselves at these wonderful tables. The Moldavian boyars of the court who were present also took part in the meal and emptied a few glasses with us to the health of their ruler, who had fulfilled towards us with so much nobility and generosity the duties of hospitality. With a full stomach and a moved heart, we bid farewell to His Highness and we set out on our way". ${ }^{27}$ And even if the departure from Wallachia did not give rise to the same warm thoughts, von Struve nevertheless remarked that they left behind the Văcăreşti monastery, which represented the location where the ruler ceased to accompany them, "in the sounds of the Russian and Turkish fanfares and of all the bells". ${ }^{28}$

In this context, it might be useful to emphasise the fact that the manner in which the envoys were received and treated was an accurate barometer of the relations between the state that had sent its representatives and the host country, not only in the short and middle term, but usually in the long run as well. ${ }^{29}$ Another relevant aspect is that in the rapports between a small political entity (such as the Romanian Principalities or Transylvania during the $17^{\text {th }}$-19th centuries) and a great power (like Sweden until the beginning of the $18^{\text {th }}$ century or Russia after the Great Northern War) images and representations played an exceptionally important role. ${ }^{30}$ As a result,

\footnotetext{
26 Ibid., 1,153.

27 Ibid., $1,127$.

28 Ibid., 1,130.

${ }^{29}$ Roosen 1980, 464-465.

${ }^{30}$ Louis Clerc, "The Eye of the Beholder: the Finns, Finland and Paris, 1870-1940," Valahian Journal of Historical Studies, no. 2 (2004): 49.
} 
even if the country that was transited by the delegates repeatedly showed its respect towards them (and by this towards the sovereigns they represented) there existed certain elements of diplomatic ceremonial that counterbalanced this apparently unequal relationship. For instance, one of the usages in force in the Romanian Principalities during the modern period was that the rulers never paid the first visit to the emissaries, but waited for them to come to court. Edvard de Carleson was just one of the diplomats who had to obey this rule, ${ }^{31}$ but, in order to avoid any error of communication, he was invited to meet John Mavrocordatos by a number of important boyars. Moreover, during the audience the Swedes are treated with the highest "signs of distinction" and after the meeting with the hospodar the travellers receive presents once again. ${ }^{32}$

Respecting the tradition regarding the part which would make the first visit allowed the Moldavian ruler "to honour His Excellency the Swedish envoy with a visit after the formal dinner" and common sense and especially the ceremonial known extremely well by both the Romanians and the Swedes obligated the latter to give thanks for the treatment bestowed upon them. Paul Jamjouglou was the one designated to present himself to the ruler's court in order to fulfil this significant task for preserving a close friendship.

It might also be interesting to note that the relations between the emissaries and the Romanian rulers were not limited to the people who actually had control over the future direction of the rapports between the two states, but involved their consorts as well. Thus, if the foreign representative was accompanied by his wife, at a given moment during their stay in the Romanian area she was going to meet the ruler's wife. And the relations between them actually bore a series of similarities to the manner in which their husbands interacted: the first visit took place at the court and afterwards the roles were inversed, expensive reciprocal gifts represented a vital necessity and expressing one's gratefulness for the presents received could not be disregarded. ${ }^{33}$

31 Cristea 2007, 139.

32 "His Excellency was led into a large hall in which the ruler invited him to take a seat to his right, giving an order to the servants to bring a couch and chairs for the rest of us. / Amongst the Moldavians only the Metropolitan or Archbishop, the bishops and only a few of the first dignitaries were seated, the rest were standing. / This audience was indeed magnificent because the court was comprised of 200-300 persons. At the end of the audience we were reled in the same way as upon the arrival. Entering our residence, a few officers presented themselves with yet still more silver vessels filled with jams and with a few bottles of a good wine, in order to thank the Swedish dignitary for his visit"; Ibid., 139.

33 The notes concerning the passage of Edvard de Carleson's deputation through Moldavia in 1746 illustrate extremely well all these ceremonial elements and Paul Jamjouglou even notes 154 
Demonstrating one's hospitality by offering banquets and/or balls seems to have been one of the most conspicuous traits of the diplomatic ceremonial of the $17^{\text {th }}$-19th centuries, in addition to the expensive presents given to the envoys of the powers with which the area inhabited by the Romanians had political connections during this period. Accompanying the emissaries, both at their arrival and at their departure, by a suite as numerous as possible was also meant to denote the host-country's appreciation of the diplomat and the sovereign whom he represented. It might be worthy to mention that the manner of expressing these signs of consideration was almost identical in Moldavia and Wallachia. ${ }^{34}$ The Ottoman influence over the Principalities and the fact that some rulers were moved from one province to the other probably played an important part from this viewpoint. The only differences noticed by the Nordic and Russian delegates referred to the presence or absence of honesty in the Moldavians' or Wallachians' relations with them: even if the Romanians were compelled by ceremonial to display certain signs of hospitality towards the travellers, they did not always do so with joy and enthusiasm. For example, Johann Christian von Struve remarked in Wallachia "the inhabitants' more reserved nature" by comparison with those of Moldavia, although he admitted that the Wallachians had solid reasons for such an attitude: "each day they had to procure large quantities of food and all sorts of fruits, as well as wines: rich meals were always prepared in the places where we arrived. These deliveries, as well as our camps' installation and the obligation to provide transportation was of course a large burden for the inhabitants who, in the last war also, had been so worn-out and who, for all these efforts, did not receive absolutely no compensation from their rulers, so that we could not take offence if sometimes they also showed gloomy faces" ${ }^{35}$

explicitly that the gifts he brought to the ruler's wife were accompanied by "the compliments that are customary in such circumstances". A rather unusual detail is the fact that the Swedes offered "two large crates with artificial flowers" to John Mavrocordatos's consort, which would mean that they were deemed precious in the epoch. For other details, see Ibid., 332.

${ }^{34}$ A clear example of this is given by Nikolai Vasilievici Repnin who, after describing in detail how the deputation to which he belonged was received at Jassy, only briefly notes that things happened in the same way in Wallachia also. For a comparison, see Călători străini..., Vol. X, part I, 204-206.

35 Călători străini..., Vol. X, part II, 1,128-1,129. Another member of Kutuzov's deputation, namely Heinrich von Reimers, admitted as well that "the country or better said the villages in the vicinity of our road were forced to procure not only those necessary for supporting the ambassador's suite, but also to place at his disposal about 1,000 pairs of oxen and 500 horses to be harnessed and a great number of large open carts, named here căruțe, for their transportation and so on. All these were owed by the good Moldavians, whose horses are not too great and neither the harnesses were not as they were supposed to be"; Ibid., 1,147. 
In a similar manner, at Bucharest, albeit "our reception and entrance to the town were just as solemn as in Jassy" and the retinue that greets them "was much larger and more brilliant than that of Moldavia's ruler", von Struve nevertheless noted that "despite all these attentions, we had the impression that we found less warmth and friendship in this reception than we had found in Moldavia". 36 Similar observations were made by Heinrich von Reimers, who discovered that in spite of the pomp displayed in Wallachia "the reception here differed like heaven and earth from that of the venerable old man Şuț. There shined, besides politeness, trust and kindness; here it can be seen that a sham friendship penetrates through politeness. There it seemed that a friend has come before another friend to greet and welcome him; here one could read on the face of the one who went to greet [us] the offended pride and the suppressed spite. In short, none of us liked the man; as we liked just as little the meal prepared in tents for the embassy". ${ }^{37}$

Apparently, music was one of the necessary ingredients of the diplomatic ceremonial in the $18^{\text {th }}$ century and some of the travellers seemed to actually enjoy this sonorous accompaniment, although they preferred the Occidental model. Johann Christian von Struve's account represents an eloquent illustration of this viewpoint: "during the meal, we could listen to the Moldavian music and to the Moldavian singers which we liked more than the Turkish music. But those who would hope to find here skilful masters like those from Germany and Italy would be utterly wrong. All their art consists in little arias and dances that are generally sung in the whole country". ${ }^{38}$ Anatoli Demidov expressed a consonant opinion on the qualities of the music he encountered in Moldavia: "a Hungarian orchestra was sent not once and came to disturb our lunches". 39

\footnotetext{
${ }^{36}$ Ibid., 1,129. Even though it is possible that the attitude of Alexander Morousis' subjects was less courteous than that of the Moldavians, the outward signs of hospitality were exhibited in the same way as in Moldavia: the Russians are seated to the left-hand side of the ruler during the meal offered in their honour, because these were the "more distinguished places", and "the large banquets, music, balls, walks at different of the ruler's manor houses, illuminations and fireworks alternated between themselves day by day".

37 The same traveller notes about the banquets from Wallachia that "here we no longer encountered the proper arrangements and the abundance of good foods, two traits that remained in our memory from the day of our entrance in Jassy. All the meals prepared for us, during all our stops from Wallachia, by the sword bearer, deceived our expectations". See Ibid., 1,166.

38 Ibid., 1,139.

39 Paul Cernovodeanu and Daniela Buşă, eds., Călători străini despre Țările Române în secolul al XIX-lea, New Series, Vol. III (1831-1840) (Bucharest: Editura Academiei Române, 2006), 654 (hereinafter: Călători străini..., New Series, Vol. III). 
The exchange of precious gifts was not disregarded by the Nordic and Russian diplomats and in their notes some of them even offered numerical estimates of the sums spent in order to purchase these presents. For instance, von Struve affirms that the Russian deputation gave Mihail Şuțu and his wife "a black fox fur, which was worth about 300 roubles, four sable skins from Kamchatka, which were worth about 400 roubles, an ermine fur, amounting to 80 roubles, ten pounds of tea and ten of rhubarb. The lady received a tuft (?) of brilliants of about 6,000 roubles, three pieces of brocade, which was worth about 300 roubles and ten pounds of tea. The presents offered in exchange consisted in golden timepieces adorned with pearls". ${ }^{40}$

The presence of tea and rhubarb amongst these objects bestowed upon the Moldavian ruler attests to their rarity in the area inhabited by Romanians ${ }^{41}$ and to their value in the epoch due to this reason. Unlike von Struve, Heinrich von Reimers, another member of General Mihail Kutuzov's deputation, was not so attentive to the pecuniary details, but he nevertheless stated that the gifts given to the Moldavian ruler and his family were "considerable", while those got in return were "very precious". Moreover, the diplomat was delighted that a few of the suite's members received small bottles with rose oil from Alexandru Moruzi, the ruler of Wallachia, the gesture being especially relevant as the presents seemed genuine because they "strongly perfumed, in a very short time, the entire contents of the travelling chest". 42

All these gestures of courtesy that were meant to show the Romanians' consideration for the envoys, although appreciated by the latter, were judged within a larger context in which Orientalism represented one of the basic elements. The similarities of ritual between the Romanian area, on the one hand, and Byzantium and the Ottoman Empire, on the other hand, did not go unnoticed. Alexandr Ivanovici Ribeaupierre asserted that in the Principalities "I was received by the rulers with all the ceremonial and pomp of the old Byzantine court. These rulers, vassals of the Sultans, were surrounded by various functionaries who once formed the court of the Byzantine emperors. I played here the role of proconsul, benefitted from all his rights and everyone bowed before me". Moreover, "each morning in my

\footnotetext{
40 Călători străini..., Vol. X, part II, 1,139.

${ }^{41}$ For other details regarding the consumption of tea in the Romanian Principalities during the $18^{\text {th }}-19^{\text {th }}$ centuries, see Mihaela Mehedinți, "Farfurii, tacâmuri şi pahare. Călători nordici şi ruşi despre alimentația românilor (secolele XVIII-XIX)," in Crucița-Loredana Baciu, Anamaria Macavei and Roxana Dorina Pop, eds., „De la lume adunate..." Lucrările Conferinței Naționale Viață cotidiană, familie, alimentație şi populație in secolele XVIII-XXI (Cluj-Napoca: Presa Universitară Clujeană, 2011), 322-323.

42 Călători străini..., Vol. X, part II, 1,156, 1,161.
} 
room some sort of a reception as in court took place; everyone honoured me and regaled me, as it also happens in Turkey to behave towards a man they all fear. The same thing repeated itself in Bucharest as well, but with much more etiquette". 43

Despite such rather negative appreciations, the emissaries' welfare continued to be one of the officials' chief concerns and Serghei Dimitrievici Urusov's visit in the Principalities in 1904 was organised down to the last detail by the Romanian authorities, who wanted to impress the governor of Bessarabia. Thus, even from the border, the Russian price travelled "in a special day coach, sent for me from Jassy" and was accompanied by the Russian consul from Ungheni, by an artillery captain and by a civil functionary. At Jassy, Urusov was greeted by a series of notabilities and was immediately informed about his accommodation as well as of the fact that "by order of the king, a palace carriage was placed at my disposal". ${ }^{4}$ The desire to please the Russian envoy was so strong that "the prefect was very embarrassed about the crowdedness from the town ${ }^{45}$ and continuously apologised to me for the defects of my lodging, which I found very comfortable". ${ }^{46}$ Consideration for the Russian Empire, represented by Urusov, was further manifested through the place he occupied when the royal pair arrived in Jassy, as well as during dinner on that same evening. The governor affirmed that each time "I had to be seated very close to the King, in the immediate vicinity of the heir to the throne's wife" ${ }^{47}$ The interest shown by Carol I towards Russia through the questions he posed to the Russian traveller, the King's and also Queen Elisabeth's friendly behaviour towards Urusov, ${ }^{48}$ as well as granting him the Order of the Crown of Romania, first class denotes the high regard that the Romanian sovereigns had for the Tsar's representative and, by extension, for Nicholas II himself.

\footnotetext{
43 Paul Cernovodeanu and Daniela Buşă, eds., Călători străini despre Țările Române în secolul al XIX-lea, New Series, Vol. II (1822-1830) (Bucharest: Editura Academiei Române, 2005), 144145 (hereinafter: Călători străini..., New Series, Vol. II).

44 Gheorghe Bezviconi, Călători ruşi în Moldova şi Muntenia (Bucharest: 1947), 441.

45 This large influx of people was caused by the fact that the Romanian ruling family was going to spend a few days in Jassy.

46 Bezviconi 1947, 442.

47 Urusov also notes that "for six days, I had breakfast and the evening meal at the palace, except a single dinner [...] and each time I was seated either beside the King or beside the Queen". Ibid., 444-445.

48 "The Queen of Romania, whose neighbour, during the breakfasts at the palace, I was three or four times, would leave aside, with much ease and goodwill, the etiquette and royal majesty. It seems that she enjoyed finding in me a representative of the Russian government, who was a novice in diplomacy, admitting before her with sincerity the lacks of his education in what regards the high- and courtly life". Ibid., 446.
}

158 
Under these circumstances, the governor of Bessarabia cannot but note that "I was extremely flattered by the attention the King showed me, of whose merits and character I had made a very high idea". ${ }^{4}$

\section{Reciprocal benevolent attitudes and courteous gestures}

Writing to Tsar Ivan IV the Terrible in the first half of the $16^{\text {th }}$ century, Ivan Semenovici Peresvetov stated that Petru Rareş was "very good-willing towards you, master, and towards your empire". ${ }^{50}$ According to the Russian traveller, the Moldavian ruler's attitude was motivated by the common faith which united the two areas. However, these affirmations must be regarded with circumspection, as it is not certain that Petru Rareş actually expressed such opinions and, moreover, Peresvetov hoped to receive a job from the Tsar as a result of this exceedingly laudatory writing composed for the latter.

On the other hand, the Romanian rulers displayed a series of signs of respect for the Russian Tsar at the end of the $16^{\text {th }}$ century as well, as Trifon Korobeinikov shows. Apparently, Aron Vodă manifested his esteem for the same Ivan IV by the fact that "rising to his feet, he asked about the Tsar's health and about his entire empire. And he commanded that the gifts that were brought to him be all placed in front of him; and at any word he spoke about the Tsar he rose to his feet". ${ }^{51}$ It is worthy to mention that these elements of the ceremony of receiving the foreign envoys remained almost unchanged until the second half of the $17^{\text {th }}$ century in both Moldavia and Wallachia, as the abbot Arsenie Suhanov illustrated in 1649 when referring to both Vasile Lupu's and Matei Basarab's courts: "And entering the palace, they [the Russian delegates] prayed to God, afterwards they bowed to Vasile voivode and gave him the Tsar's letter. And the voivode Vasile rose to his feet, received the Tsar's letter and gave it to his chancellor. And Arsenie, after he handed over the Tsar's letter, withdrew and took an icon overlaid with metal and gave it to the voivode. Afterwards the chancellor ordered Arsenie to come and kiss the voivode's hand. The abbot Arsenie kissed the voivode's hand, withdrew, bowed and then rose to his feet. And the chancellor unsealed the Tsar's letter and read it in front of the voivode. And Vasile

\footnotetext{
49 Ibid., 448.

50 Maria Holban, ed., Călători străini despre Țările Române, Vol. I (Bucharest: Editura Ştiințifică, 1968), 453 (hereinafter: Călători străini..., Vol. I).

${ }^{51}$ Maria Holban, M. M. Alexandrescu-Dersca Bulgaru and Paul Cernovodeanu, eds., Călători străini despre Țările Române, Vol. III (Bucharest: Editura Ştiințifică, 1971), 353 (hereinafter: Călători străini..., Vol. III).
} 
voivode, after he listened to the Tsar's letter, asked about the Tsar's health, rose to his feet and took off his fur cap" .52

As could be inferred from these descriptions, one of the main traits of the modern epoch's diplomatic ceremonial is that it was bestowed upon the representatives of the one for whom it was actually intended. 53 Of course, this rule was applied irrespective of the country of origin and thus a similar treatment was given to Paul Strassburg as well, the emissary of the Swedish king Gustav Adolf II to Leon Tomşa: in the envoy's presence, the Wallachian ruler "raising a large cup toasted to His Majesty's health and triumph [and at that moment] a few catapults and copper cannons fired with such reverberation that the ruined building shook and even the dishes from the table hit each other". ${ }^{\prime 4}$

Iohann Mayer actually explicitly noted that the way in which Vasile Lupu behaved towards himself was mostly motivated by the respect the latter had for Queen Christina of Sweden and that he "received me in the friendliest manner and [...] consented that I would be escorted as far as the Polish border by his men and this not as a result of the letter of the minister of war, but in honour of the all-glorious Queen of Sweden, my merciful sovereign. [...] He then asked me to wish Her Majesty the Queen a long life and much luck in her rule on his behalf <and> he wished me a good trip" ${ }^{55}$

Nonetheless, within this context one should not disregard the fact that any type of ceremonial represents a sum of conventional and standardised behaviours, essentialised to a rather high degree and playing the role of symbols for certain attitudes and opinions. Moreover, all the gestures involved in these activities are governed by clear rules according to which form is almost as important as the content. ${ }^{56}$ Therefore, decades or centuries of practice are necessary in order to achieve this "stylisation" that does not permit the existence of any equivocalness.

Fortunately, this condition was satisfied by the Romanian diplomacy during the modern period and the facilitations that Korobeinikov and his companions enjoyed during their journey prove that certain usages were in force even in the $16^{\text {th }}$ century. While on Moldavia's territory, they received supplies and guides, they were exempted from paying any customs duties and they were offered a number of "letters of passage".57 In the same

\footnotetext{
52 Almost the same words are used to describe the ceremony which took place at Matei Basarab's court. For a comparison, see Călători străini..., Vol. V, 404, 406.

53 Roosen 1980, 455.

54 Călători străini..., Vol. V, 65.

55 Ibid., 451.

56 Roosen 1980, 454-455.

57 Călători străini..., Vol. III, 353.

160
} 
manner, the keen interest in ensuring a communication as correct as possible with the foreign delegates demonstrates that the Romanian rulers understood the importance of diplomacy. Such an example is provided by Conrad Iacob Hiltebrandt: the pastor affirmed that the response given by the Transylvanian chancellor to the Swedish envoys in the Latin language, after the latter presented their mission to the prince, had been studied for eight days. 58

The first half of the $18^{\text {th }}$ century brought along new signs of goodwill towards the foreigners who were transiting the territories inhabited by Romanians. For instance, in 1707 monk Ipolit Vîşenski had nothing to reproach Mihail Racoviță, as the Moldavian ruler "received everything with love; he received us very mercifully and kindly and alone ordered with his own mouth that we were to have everything we need and gave us an ukase until the borders of Wallachia, so that everywhere we would be given two horses and a man for each cart, as well as a leader". 59

John Bell of Antermony, the Russian envoy who passed through the Romanian area in 1738 also benefitted from consideration from the part of the Moldavian authorities. The latter provided him with wine and fruits, "which was not to be despised in a place where few things could be bought with money", and facilitated his transportation to Jassy. In addition to all this, the audience with Grigore II Ghica was characterised by "great honour and politeness" and the accommodation he occupied in the Moldavian capital was appreciated by the diplomat especially because it was "well heated", a quality that was particularly relevant as his visit took place in January. ${ }^{60}$

\footnotetext{
58 Călători străini..., Vol. V, 557. This statement is illustrative for the tendency to replace the Latin language with the vernacular ones, a tendency that made its presence felt amongst the Hungarian nobility from Transylvania beginning with the $16^{\text {th }}-17^{\text {th }}$ centuries. For details, see Ionut Costea, "Language and Identity: The Nobility of Pre-modern Transylvania." Transylvanian Review Vol. XIII, no. 1 (2004): 71. During the same period, the Moldavian Orthodox clergy replaced the Slavonic language with the Romanian one when drawing up documents. See Bogdan-Petru Maleon, “Între slavonismul cultural şi scrisul în limba română: clerul de mir ortodox din Moldova medievală," in Andi Mihalache and Adrian Cioflâncă, eds., In medias res. Studii de istorie culturală (Jassy: Editura Universității „Al. I. Cuza”, 2007), 337-338.

${ }^{59}$ Maria Holban, M. M. Alexandrescu-Dersca Bulgaru and Paul Cernovodeanu, eds., Călători străini despre Țările Române, Vol. VIII (Bucharest: Editura Ştiințifică şi Enciclopedică, 1983), 245 (hereinafter: Călători străini..., Vol. VIII).

${ }^{60}$ Maria Holban, M. M. Alexandrescu-Dersca Bulgaru and Paul Cernovodeanu, eds., Călători străini despre Țările Române, Vol. IX (Bucharest: Editura Academiei Române, 1997), 193-194 (hereinafter: Călători străini..., Vol. IX).
} 
A century later, another Russian, Anatoli Demidov, was likewise treated remarkably well by Bucharest's elite, ${ }^{61}$ despite the fact that he was not fulfilling an official mission. Even the ruler, Alexandru Ghica, showed a particular consideration for his visitors so that "the reception full of goodwill and cordiality with which we were greeted allowed us to appreciate this prince's varied knowledge". The ruler's friendliness proved to be extremely useful to the travellers, who were given all the necessary facilitations for their travel, ${ }^{62}$ while the Wallachian functionaries with whom they came into contact were also ready to welcome Demidov and his companions by displaying a courteous attitude. Moreover, the Russians discovered that "at Jassy as in Bucharest we were protected by the most noble and amiable hospitality" and Mihail Sturdza demonstrated his "remarkable eloquence" and "distinct instruction" as well. ${ }^{63}$

However, sometimes problems regarding ceremonial could appear because it had to simultaneously take place at two different levels: that of the envoy present and that of the sovereign he represented. Thus, the manner of treating a country's emissaries illustrated how that state and its ruler were regarded by the other powers and, as a result, not granting certain privileges or disregarding particular gestures of courtesy could, in some cases, lead to declarations of war. ${ }^{64}$

Fortunately, situations of this kind were exceptionally rare in the Romanian area, but, on the other hand, the occurrence of some slight misunderstandings that could pose difficulties to the foreign delegates was much more frequent. Serghei Dimitrievici Urusov anticipated that "the Romanians value very highly the Russian government's act of politeness towards their king and [...], caring about pomp and brilliance, they will seek to give my arrival a great importance and an aspect of solemnity". ${ }^{65}$ For this reason, during his visit in 1904, the shy governor of Bessarabia was put in a few awkward situations, although the Romanian monarchs merely intended to manifest their extreme appreciation of the Russian envoy and the one he was representing: "After the royal family's arrival at Jassy, all my time, from

\footnotetext{
61 "During this first day, a few received and paid visits began to give us a general idea about Bucharest and its inhabitants. In the rest, we were the object of such a distinguished politeness, so that even from the first hours our time was constrained to a much longer stay than the one that we could have afforded to devote to this obliging hospitality"; Călători străini..., New Series, Vol. III, 611.

62 "For our journey forty horses had been prepared and the ruler's noble caution had gone to such an extent that he had sent couriers ahead of us in order to ensure an irreproachable service: in this manner we have travelled with an extreme speed"; Ibid., 625.

63 Ibid., 652-653.

64 For more details, see Roosen 1980, 456, 462-463.

65 Bezviconi 1947, 441.

162
} 
9 in the morning and until 12 at night, was occupied by the schedule. Each morning solemn religious services took place, with the occasion of the restoration, at the King's expense, of the different old Orthodox churches from the ancient Romanian capital. I had to receive the royal family when they entered the church and, in my capacity as representative of the most Orthodox country, not only to attend the divine service, but also to directly take part in all the religious ceremonies: with much zeal I poured water on all the altars that were being consecrated, I wiped with [a] sponge their surface, I rubbed cement with the shovel and executed, after the royal family, under the guidance of the metropolitan and of the archbishops all that was fitting according to the consecration customs. King Carol watched with a great deal of attention that I would not lose my turn, coercing me to fulfil my role immediately after the little prince Carol. The Romanian clergy manifested, for its part, a distinct attention towards me; the archdeacon of the cathedral once deemed fit, during the liturgy, to make a gesture of particular courtesy towards the Russian representative: coming to the pulpit and casting a glance at me, he read from a small piece of paper the prayers in the Slavic language, while all those present turned their eyes towards $\mathrm{me}^{\prime \prime} .66$

It is important to emphasise that in some cases such feelings were mutual: travellers exhibited signs of fondness for the Romanians and sometimes these were highly visible. For instance, Peter the Great's visit to Jassy in 1711 offers an illustration of both the habitual relationship between two rulers, even if they were not of the same calibre, and also some peculiarities stemming from the interlocutors' personalities. An example of this latter affirmation is the fact that when Peter the Great met his new "vassal", Dimitrie Cantemir, "with his sinewy arms, the Russian, who had received the kissing of the hand, lifted his host towards the skies, then kissing him on the crown of his head". On the other hand, the custom regarding the meeting of the wives of the two protagonists of the scene described above was respected precisely and Casandra, the Moldavian ruler's consort, received as a gift a medallion with Tsarina Elisabeth's portrait. Organising a feast for the illustrious guest was likewise related to the "normal" gestures of politeness in these situations and the Moldavian wine was highly praised by the Russians. But, once again, the Tsar behaved in a somewhat atypical manner for the given circumstances and demonstrated more courtesy towards Cantemir than it would have been necessary: "The Tsar showed himself full of amiability towards his host,

66 Ibid., 447. 
whom he gave the place of honour at the table, kissing him again, both at the beginning and when the glasses were raised". ${ }^{67}$

Despite the fact that he was at war with Sweden, Peter the Great even had time to go strolling in Jassy and he declared himself especially impressed by the Golia monastery. The Trei Ierarhi monastery was also visited by the Russian sovereign, who was eager to worship Saint Paraschiva's relics. Moreover, during the religious service, Peter the Great stood, as any other believer, refusing the honour of occupying the ruler's pew, an honour that was in accordance with his rank. ${ }^{68}$ And these gestures of friendship did not go unnoticed: the Moldavians greeted him in large numbers on the streets and his presence was announced by ringing the bells. 69

Alexandre de Langeron is another traveller who behaved in a manner that was not characteristic of the majority of his compatriots and gave the impression of solidarity with the Romanian people by demonstrating sensibility towards the sufferings the latter was subjected to during the Russian-Austrian-Turkish wars. Notwithstanding, this sympathy did not surpass political reasoning in intensity and thus, albeit the general admitted that the Russians had already plundered Wallachia enough, he still considered that they needed to subjugate Moldavia as it was "very important to us". ${ }^{\prime 0}$

Whilst appreciating the treatment bestowed upon them during their passage through the Romanian Principalities by the Moldavian and Wallachian rulers, some Nordic and Russian diplomats were also aware of the efforts and costs entailed by these deputations for the locals. Some of the envoys tried to assuage their consciousness by rewarding the Romanians involved in providing the goods and services required by the delegations. For example, Heinrich von Reimers confessed that "out of pity for the poor people, the four of us ${ }^{71}$ decided, as some sort of law, that each day we would give a certain amount both to our carriage's coachman and to those who, behind us, brought in the cabriolet our common luggage". ${ }^{72}$

\footnotetext{
67 Nicolae Iorga, "Carol al XII-lea, Petru cel Mare şi Țările Noastre (1709-1714)," Analele Academiei Române. Memoriile Secțiunii Istorice Series II, Tome XXXIII (1910-1911): 96.

68 Ibid., 98.

69 See also Bezviconi 1947, 90-91.

${ }^{70}$ However, placed in a larger context, the territories held by Russia in Europe were, from Langeron's viewpoint, less important than those from Asia. For details, see Paul Cernovodeanu, ed., Călători străini despre Tările Române în secolul al XIX-lea, New Series, Vol. I (1801-1821) (Bucharest: Editura Academiei Române, 2004), 352-353 (hereinafter: Călători străini..., New Series, Vol. I).

${ }^{71}$ Himself and three other members of Mihail Kutuzov's delegation.

72 Călători străini..., Vol. X, part II, 1,147.

164
} 
The Russian military authorities likewise acknowledged that at the beginning of the $19^{\text {th }}$ century "the discipline was so weakened that plundering was, so to say, part of the daily agenda. The military men took from merchants almost all they liked". Pavel Vasilievici Ciceagov, sent in the Principalities precisely in order to put an end to this state of affairs, demonstrated that he was capable of a benevolent attitude towards the inhabitants subjected to these abuses. Nevertheless, it should be mentioned that his motives were strongly related to the attempt to obtain an income as high as possible from the Romanian provinces for his government, a desideratum that could not be achieved unless order was restored and thus, in the administrative sector, "it was especially urgent to hamper the officials" peculations and thefts, tolerated until then by chiefs accustomed to commit arbitrary acts and who meddled as they each fancied with local matters". Whilst striving to normalise the situation, the Russian admiral notes that he was compelled "to apply exemplary punishments to some soldiers who, being members of my guard of honour, had taken the liberty of collecting supplies from houses neighbouring my own. And still I was not always able to cease these excesses. One day, a culprit was placed under arrest, but, finding the means to escape, he placed himself under the French consul's protection, where I was forced to tolerate his guilt". ${ }^{73}$

Russia's apparent concern for the Romanians' welfare was also brought to the fore by Ignati Iakovenko in 1820. The diplomat reminded his readers that the Moldavian and Wallachian rulers were guided by the ambition of enriching themselves as soon as possible, because the duration of their dominion was often random. Russia's encroachments on the Principalities were consequently presented in a positive light: the Tsars did not have their own interests at heart, but they were trying to improve the Romanians' condition. Unfortunately, avarice usually prevailed over moral considerations: "Russia had always shown a distinct care in its desire to dam the hospodars' insatiable greed, succeeding in ensuring their rule for 7 years, so that it would have made each of them be satisfied, in the course of these years, with revenues granted especially to them and which, during 7 years, formed a rather considerable sum. But, later on, with regret it was discovered that the prejudicial system of increasing the hospodars' revenues, with all the advantages granted earlier, continued to be practiced, their measureless greed imagining new means and tricks for collecting all sorts of taxes, under different pretences, by subjecting the people even nowadays to an unbearable yoke, completely impoverishing it".$^{74}$

73 Călători străini..., New Series, Vol. I, 546-547.

74 Ibid., 822. 


\section{Diplomatic relations between the area inhabited by Romanians and the Nordic countries during the $17^{\text {th }}-19^{\text {th }}$ centuries}

The connections between the Romanians and the Scandinavian states weakened after the end of the Great Northern War. Due to the fact that, amongst the Nordic countries, Sweden had played the most important role in maintaining certain rapports with Transylvania and the Danubian Principalities, one might assume that, after the former declared its neutrality in 1815, the political and diplomatic relations between the Nordics and the Romanians diminished to the brink of extinction. However, the two areas continued to interact, even if this occurred rather scantily. For instance, although it had no repercussions for Moldavia or Wallachia, the DanishGerman dispute over the duchies Schleswig and Holstein influenced some of the great powers' decisions regarding Southeast Europe. ${ }^{75}$ In a similar manner, Sweden's or Denmark's involvement in the question of the ad hoc assemblies and the Principalities' union was almost nonexistent, because, as secondary powers in this matter, they did not really have a word to say ${ }^{76}$ (assuming that they would have had some sort of interest one way or the other). Nevertheless, the benevolent neutrality that they displayed surely did not do any disservice to the Romanians.

On the other hand, the Romanian War of Independence occasioned the establishment of personal relationships between the Norwegian officer Gunar Sölfest Flood and a series of personalities pertaining to the Romanian government and army ${ }^{77}$ and even King Carol I treated him extremely graciously. Furthermore, prime minister Ion C. Brătianu did not forget about Flood's presence in a festive moment and "he spoke, addressing himself to me, for Norway, Sweden and their King. I responded through a toast to Romania's royalty. I pledged to convey the beautiful salutations to $\mathrm{H}$. $\mathrm{H}$. King Oscar and then, as a sincere royalist, I said (perhaps not entirely diplomatically): 'I had the honour and joy of being present in the night when the Romanian Chamber of Deputies has protested for the first time against the new Turkish Constitution, now we had at Plevna the protestation of the Romanian cannons and I hope to hear the third and final protestation - the proclamation of the Romanian Kingdom. (I drink this glass) to the glory and prosperity of beautiful Romania'" ${ }^{.78}$

\footnotetext{
75 For details, see L. Boicu, V. Cristian and Gh. Platon, eds., România în relațiile internaționale 1699-1939 (Jassy: Junimea, 1980), 174-184.

76 Ibid., 158.

77 For example, with general Cernat and with major Romulus Magheru.

78 General R. Rosetti, Notele unui ofițer norvegian inaintea şi în timpul Răsboiului de Neatârnare 1876-1878 (Bucharest: Cultura Națională, 1928), 56-57. 
Besides Flood's presence on Romania's territory during the War of Independence, the eighth and ninth decades of the $19^{\text {th }}$ century witnessed two visits paid by members of the Swedish ruling family, namely that of prince heir Oscar Gustav Adolf in 1879 and that of King Oscar II and Queen Sofia in 1885. Obviously, aside from the family ties that bound the two states' sovereigns, these events were also relevant from the perspective of the diplomatic connections between the two states, despite the fact that the latter visit was not an official one. ${ }^{79}$

The first of the two above-mentioned journeys, that of Oscar Gustav Adolf to Bucharest, took place at approximately the same time with that of the Romanian delegates who went to Stockholm in order to notify King Oscar II that their country had recently obtained its independence. In reality, the arrival of the diplomatic mission in the Swedish capital and that of the Swedish prince in Bucharest were carefully synchronised and, moreover, the Romanian authorities did all that was in their power to make sure that the Swedish prince reached his destination in the best possible conditions. Of course, this happened a few years later as well, in the case of the Swedish monarchs' voyage. Actually, this latter trip was occasioned by personal reasons and the Nordic sovereigns were heading towards the Ottoman Empire, where one of their sons had become seriously ill, forcing the concerned parents to hurry to his side. Notwithstanding, Oscar II's and Sofia's passage through Romania was by no means neglected and they were treated according to their ranks. Furthermore, both the official reception and the greeting given to them by Bucharest's inhabitants were very warm.

As for the strictly diplomatic relations, it must be noted that there existed a number of ties between Sweden and the Romanian area even before 1859. The Swedish consulates in Bucharest, Galați, Brăila and Constanța, as well as the corresponding ones in Stockholm, Göteborg and Malmö80 ensured the necessary communication between the two states. Besides, special events received an enhanced attention. For instance, after Romania acquired its independence, Prince Basarab Brâncoveanu was sent in a special mission to Stockholm and Copenhagen in order to notify this change in the country's status. Kings Oscar II of Sweden and Christian IX of Denmark were thus apprised of the Romanian victory in the War of Independence in the period March-April 1879 (24 March/5 April and 2/14 April, respectively). ${ }^{81}$ In a similar manner, Carol I was informed on 15/25 November 1905 by

\footnotetext{
${ }^{79}$ For details, see Cristea 2007, 189-214.

80 Ion Hurdubețiu, Istoria Suediei (Bucharest: Editura Ştiințifică şi Enciclopedică, 1985), 354.

81 Ion Calafeteanu and Cristian Popişteanu, eds., Politica externă a României: dicționar cronologic (Bucharest: Editura Ştiințifică şi Enciclopedică, 1986), 138. See also Hurdubețiu 1985, 354.
} 
Haakon VII of Norway about the dissolution of the union between Sweden and Norway and about his election as king of the new independent state. ${ }^{82}$

The next highly relevant episode in the relations between the two areas took place a decade later, in 1916, when the Romanian legation in Sweden was established, Grigore Bilciurescu being the first Romanian representative to Stockholm. ${ }^{83}$ The legation functioned from 1 November 1916 until 1 August 1929,84 when it was closed due to budgetary causes. Notwithstanding, it was later reopened and was functional even during the Second World War.85 As in the case of the Romanian diplomatic representation in the Nordic state, the first envoy extraordinary and minister plenipotentiary of Sweden to Bucharest, namely Hans Ioachim Beck Früs, presented his letters of accreditation to King Ferdinand in March 1916.86

However, the two states had already adopted a few comparable foreign policy decisions. For example, on 17/29 July 1899 a Convention for the peaceful settlement of international disputes was signed at Hague by 26 states, amongst which Romania, Denmark, The United Kingdoms of Sweden and Norway and Russia. ${ }^{87}$ Moreover, in 1910 Romania concluded conventions of commerce and navigation with Sweden and Norway and a commercial one with Denmark. 88

Likewise, at the beginning of the First World War both Sweden and Romania opted for non-involvement. As in Romania's case, Sweden's neutrality was not easily accepted by the belligerents, which hoped to draw the Nordic country into an eventual alliance. But it must be mentioned that,

\footnotetext{
82 Calafeteanu and Popişteanu 1986, 151.

83 Claudiu-Lucian Topor, "German policy and the diplomatic agenda of Romanian neutrality (1914-1916). The prospects for an alliance with Sweden," The Romanian Journal for Baltic and Nordic Studies Vol. 3, Issue 1 (2011): 135. George Cristea, "Călători români în Suedia (secolele XVII-XX)," in Bocşan Nicolae and Ioan Bolovan, eds., Călători români în Occident. Secolele XVIIXX (Cluj-Napoca: Institutul Cultural Român, 2004), 165 spells the Romanian diplomat's name differently, namely "Bâlciurescu".

84 The Romanian representatives at Stockholm were Grigore Bilciurescu, from the legation's inauguration until May 1917 (when he became the chief of the newly established legation in Christiania), Gheorghe Derussi, between May 1917 and September 1919 and Mihail M. Pâcleanu, who was a minister plenipotentiary to the Swedish capital from September 1919 until 1927. See Cristea 2004, 165.

85 Istoria României în date, elaborated by Dinu C. Giurescu, Horia C. Matei, Nicolae C. Nicolescu, Marcel D. Popa, Gheorghe Rădulescu, Alexandru Stănciulescu, coordinator Dinu C. Giurescu (Bucharest: Editura Enciclopedică, 2003), 898.

86 Calafeteanu and Popişteanu 1986, 160.

87 Ion Ionaşcu, Petre Bărbulescu and Gheorghe Gheorghe, Relațiile internaționale ale României in documente (1368-1900). Culegere selectivă de tratate, acorduri, convenții şi alte acte cu caracter internațional (Bucharest: Editura Politică, 1971), 478-491.

88 Calafeteanu and Popişteanu 1986, 154.

168
} 
although in the context of the war there existed a number of resemblances between the two countries, ${ }^{89}$ the neutrality adopted by the Nordic country was dissimilar to Romania's refusal to participate in the conflict until 1916. For instance, Sweden had no intention of ever entering the war, while Romania was only trying to take the best possible decision regarding the side that should be chosen. Furthermore, the Swedes had the tendency to favour the Germans, while the Romanians mostly supported the Entente's actions. ${ }^{90}$ Nevertheless, there existed sufficient motives to speak about both Romania's and Sweden's potential alliance with Germany against Russia, the common enemy, and Alexandru Beldiman, the Romanian envoy to Berlin, invoked a series of arguments for this course of action. But such a pact was not accepted by the Bucharest government, even if it could have had clear benefits, and the Swedish indecision and pacifism were doubled by the lack of interest and the nationalism manifested by the Romanian political circles. ${ }^{91}$

Norway and Denmark desired to remain neutral during the war as well and they both considered that signing a treaty with Sweden would be the best way to achieve this objective. From the viewpoint of maritime commerce, the Norwegians held a position that was close to that of Great Britain and the German militarism and imperialism were other reasons that alienated them from the interests of this "central power", despite the fact that the Russian threat was extremely disquieting as well.

Hence, not only the Swedish-Romanian connections, but also the diplomatic relations between Romania, on the one hand, and Denmark and Norway, on the other hand, actually became stronger during the First World War and May 1917 witnessed the establishment of the Romanian legations in Copenhagen and Christiania. ${ }^{92}$ In Denmark the legation functioned from 1 May 1917 until 20 June 1934, Gheorghe Derussi, Romania's representative

\footnotetext{
89 The similarities noted by Claudiu-Lucian Topor are: the fact that both countries had Central Powers as neighbours, the importance of the German economy within their national economies, the inclination of a part of the intellectual circles towards the German culture, the serious internal crises with which the two states were confronted during the first decade and a half of the $20^{\text {th }}$ century, the suspicious attitude towards Russia and the fact that Germany could have offered a certain sense of security against the former and, respectively, the fact that the fulfilment of their national interests imposed the participation in the war either alongside the Germans and against the Russians, or alongside the Russians against AustroHungary. Besides all this, both countries' neutrality brought them commercial benefits: despite the blockade from the North Sea, Sweden exported iron ore, wood and food, while Romania exported cereals and vegetables. See Topor 2011, 132-134.

90 The Swedish telegraph service transmitted German messages. On the other hand, Romania did not allow the transport of German armaments towards Turkey on its territory, but accepted the Allied one towards Serbia. For more details, see Ibid., 133.

91 Ibid., 136-140, 142.

92 Calafeteanu and Popişteanu 1986, 163. See also Istoria României în date 2003, 889, 895.
} 
to Stockholm, being also accredited to Copenhagen in August; after this date, the Romanian state appointed George Assan as its envoy. In Norway, Grigore Bilciurescu became Romania's first chargé d'affaires here in the month of June, but the legation served its purpose only intermittently, because after six years from its establishment (1 May 1917 - 1 April 1922) it was suppressed due to economic problems until 1 February $1928^{93}$. After this latter date, Romania's minister to Stockholm was accredited to Oslo (the Norwegian capital's new name from 1925) as well.

As for the relations with Finland, Romania's diplomatic representation at a consular level in the "country of a thousand lakes" dates back to 1890, when the initiative of the Finnish merchant Edvard Evensen was accepted by the Romanian authorities and he thus became Romania's first vice-consul to Helsinki. ${ }^{94}$ Given that Finland was at that moment one of Russia's provinces, Alexander III's approval was needed in order for this appointment to become valid; fortunately, the Tsar expressed his consent on 17 June 1891. After seven years, this vice-consulate became a consulate and then a consulate-general on 20 May 1926.95 It should be noted that from 15 February 1921 to 1 April 1922 a Romanian legation in Finland functioned as well, Dimitrie Plesnilă being the first Romanian diplomat accredited to Helsinki. However, the legation was suppressed in 1922 (until 1 June 1932) owing to financial issues, but its activity was resumed when Romania's envoy to Stockholm was also accredited to Helsinki. ${ }^{96}$

The Finnish legation in Bucharest was established in June 1920, three years after Finland became independent. Väinö Tanner was initially chargé d'affaires and on 26 June 1921 he was appointed envoy extraordinary and minister plenipotentiary. ${ }^{97}$ Interestingly enough, Romania was one of the first states to recognise the Finnish state's sovereignty, on 8 April 1920.98

\footnotetext{
93 Calafeteanu and Popişteanu 1986, 179.

94 "State Secretary at the Ministry of Foreign Affairs Bogdan Mazuru's Address on the Occasion of the 90th Anniversary of the Establishment of Diplomatic Relations between Finland and Romania," The Romanian Journal for Baltic and Nordic Studies Vol. 3, Issue 1 (2011): 184.

95 "Speech by President of the Romanian Association for Baltic and Nordic Studies Dr. Silviu Miloiu on the Occasion of the 90th Anniversary of the Establishment of Diplomatic Relations between Finland and Romania," The Romanian Journal for Baltic and Nordic Studies Vol. 3, Issue 1 (2011): 190-191.

96 Istoria României în date 2003, 890.

97 "State Secretary..." 2011, 184-185.

98 "Speech by H. E. Ambassador of Finland Ms. Irmeli Mustonen on the Occasion of the 90th Anniversary of the Establishment of Diplomatic Relations between Finland and Romania," The Romanian Journal for Baltic and Nordic Studies Vol. 3, Issue 1 (2011): 189.

170
} 
Although in general the relations between the two states were good during the first half of the $20^{\text {th }}$ century, the Finnish diplomatic reports on Romania (and on other central and eastern European countries) are filled with negative appreciations. What the Finnish envoys criticised most was the fact that politics seemed to be a "passionate national sport" and that "things did not run smoothly and by the book", but depending upon interpersonal connections and bribes. ${ }^{99}$ This type of behaviour was mainly explained through the presence of flaws in the national character and hence the diplomats inadvertently flattered themselves and their people in order to consolidate a positive self-image. As a result, the Finnish (and, by extension, the Nordics) became a model of correctness that had to be copied by the countries from the part of the world had in view.

These attitudes were further maintained during the 1930's and the Finnish representative to Bucharest displayed very harsh reactions with reference to the political system with which he was compelled to come into contact. The most frequent opinions about the Romanians referred to corruption (especially the bribes' perenniality and weight in the decisionmaking process), to the electorate's lack of political culture, to the politicians' sustained interest in solving private affairs and in Romantic idylls or to the absence of real parliamentary debates (because the majority of the deputies were members of the party that was in power). 100 Unfortunately, Romanian readers have to admit that things have not changed too much since the interwar period...

\section{Diplomatic relations between the Romanian rulers and the Russian Empire (17th-19th centuries)}

Alongside generals, emissaries represent the most important strategic "weapons" that any state has at its disposal in its ties to another political entity. Resorting to military means in order to regulate certain disputes can be avoided, delayed or accepted without reserve by a sovereign depending upon the information he receives from his foreign delegates. Therefore, "the game in which the diplomat engages is the durable knitting of interests in the fundamental act of negotiation, which constitutes the supreme test of his value". ${ }^{101}$

\footnotetext{
99 Vesa Vares, " «Never satisfactory, according to the Finnish standards». From optimism and interest to disappointment and disillusion: Finnish views on the nations in Eastern Central Europe between the world wars," The Romanian Journal for Baltic and Nordic Studies Vol. 3, no. 2 (2011): 238-239.

100 Ibid., 239-241.

101 Mircea Malița, “Diplomatul în istorie. Introducere la o galerie de portrete," in Diplomați iluştri Vol. I (Bucharest: Editura Politică, 1969), 6.
} 
It then becomes obvious why, in addition to the clear advantages that the existence of diplomatic representation in another country habitually brought, particularly in the case of the political and economic connections between the two states, it could also lead to unpredictable situations that could generate conflicts. Such an example is provided by Nikolai Vasilievici Repnin, who, acting in Russia's name, started to be regarded by the Moldavians as exercising a certain ascendancy over the ruler. Consequently, when he passed through Jassy in 1775, the inhabitants complained to him about Grigore III Alexandru Ghica, especially as the Moldavian hospodar owed his throne to the Russian aid. Albeit he enjoyed the influence he had in the Romanian Principalities, the foreign diplomat had to admit that this initiative put the Empire he represented in a rather delicate position: on the one hand, a refusal to respond to these requests would have shattered the Moldavians' trust in Russia's desire to help them, but, on the other hand, an attempt to hold Grigore Ghica responsible for any wrongdoings could be seen as a transgression by the Ottoman Empire. The solution found by Catherine II was to ask Repnin to address the matters in question to the competent forums and thus solve them through the ruler's mediation; the only situation in which the Russian emissary was mandated to convey these expressions of discontent to the Sultan was if the Moldavians explicitly asked him to do so. ${ }^{102}$

A decade later, Ivan Ivanovici Severin was faced with the same predicament, only this time it was more specific: the ruler had forbidden the use of swings during Easter. Unfortunately, Severin did not deal with the problem as well as Repnin and antagonised Alexandru Mavrocordat. In actuality, the dissension had been caused by the fact that Jassy's inhabitants sought the Russian consul's help and did not go directly to the ruler; hence, if the latter had responded favourably to Severin's intervention, the Ottomans could have considered him to be "the Russians' man". After Mavrocordat gave him this explanation, the Russian envoy merely noted that "however it was, it was discussed in all the homes and I was told that the people's attachment to us is exceptional". ${ }^{103}$

The following decades provided other proofs of this "attachment", but they also witnessed incidents and difficulties brought about by the series of wars that took place on the Romanian territory. Within this context, an episode as important as the double election of Alexandru Ioan Cuza as ruler of Moldavia and Wallachia clearly had the potential to give rise to diplomatic issues, which, fortunately, were only minor. So, even though it did not

\footnotetext{
102 Bezviconi 1947, 116-117.

103 Călători străini..., Vol. X, part I, 655.

172
} 
uphold the act achieved by the Romanian politicians, the Russian government acknowledged it, as demonstrated by the fact that they would not have participated alongside the Ottomans in an eventual military intervention in the Principalities. ${ }^{104}$

On the other hand, a number of events that took place during Cuza's rule illustrate the way in which the Romanian and Russian diplomats dealt with other situations that could transform themselves into serious crises. For instance, Romania permitted and even assisted a terrestrial Russian armaments shipment towards Serbia in 1862. In exchange, the Tsar had to refrain from getting involved in the question of the secularisation of the monastic estates, an obligation that the Russian sovereign respected only until the outbreak of the Polish revolt which immediately followed. The (unofficial) support reaction exhibited by the Romanians for the Poles, who found themselves in the process of affirming their nationality (and were, consequently, similar to the Romanians), strained the relations between the young state ruled by Cuza and the Russian Empire. Nevertheless, a slight amelioration of the rapports between the two countries occurred after Romania forcefully prevented a group of armed volunteers from crossing its territory in an attempt to reach Poland; a different course of action adopted by the Romanian side would have seriously shaken its claims of neutrality and would have certainly generated a harsh Russian response. ${ }^{105}$

Notwithstanding, after this significant moment and especially after the monastic estates were transferred to the state's treasury, Alexandru Ioan Cuza started to be regarded with growing suspicion by the Tsar's government. This is why his deposal at the beginning of 1866 was saluted by the Russian diplomats from the Principalities, but the possibility that Russia might lose some of the influence it had in the Romanian area if a prince of a foreign origin acceded to the throne was taken into consideration as well. Thus, the election of Carol I of Hohenzollern-Sigmaringen was recognised by Alexander II only after the future king displayed a benevolent attitude towards the Tsar: amongst other reassuring gestures and promises, Carol I took it upon himself to do everything within his power in order to stop the ongoing revolutionary activities and to protect, through the institutions of the state, the Orthodox Church.106

Ironically, given the tensions from the first half of the $19^{\text {th }}$ century, some of which were briefly presented above, the United Principalities' first

\footnotetext{
104 Marian Stroia, “Rusia şi românii. De la războiul Crimeii la cucerirea independenței. Repere diplomatice (1855-1878)," in Daniela Buşă and Ileana Căzan, eds., Românii şi geo-politica marilor puteri 1718-1918 (Bucharest: Oscar Print, 2009), 59-60.

105 Ibid., 61-64, 65-67.

106 For more details on this matter, see Ibid., 73-75, 78-79.
} 
international convention with another state was the telegraphic one concluded with Russia in December 1860, which came in force two years later. ${ }^{107}$ Similarly, the first postal convention was also signed with Russia, at the end of 1867.108 These were followed by the Romanian-Russian convention that stipulated the junction of the two states' railways between Jassy and Kishinev, signed in May 1872,109 and by a convention of commerce and navigation, concluded in March 1876.110

Furthermore, this period marked the beginning of Romania's representation in Russia, as the Romanian diplomatic agent to Vienna was also accredited to Sankt Petersburg in 1869.111 Three years later, on 6 May 1872 , he was replaced by the Romanian envoy to Berlin and in 1874 Romania established a diplomatic agency in the Russian capital, an agency that was transformed into a legation in 1878.112 The latter functioned until 13 January 1918,113 when the Bolshevik government broke off the diplomatic relations with Romania until 1934.

The obvious improvement in the Romanian-Russian rapports in the second half of the $19^{\text {th }}$ century allowed G. I. Bobrikov to set forth the image of a few close personal relationships between some of the Russian diplomats who found themselves in the Principalities on the eve of the War of Independence and certain members of the Romanian government. According to his account, a simple amiable discussion could solve numerous problems and conflicts occasioned by the presence of the Tsarist troops on the Romanian territory. ${ }^{114}$

107 Istoria României în date, elaborated by Dinu C. Giurescu, Horia C. Matei, Nicolae C. Nicolescu, Marcel D. Popa, Gheorghe Rădulescu, Alexandru Stănciulescu, coordinator Dinu C. Giurescu, Second revised and enlarged edition (Bucharest: Editura Enciclopedică, 2007), 200.

108 This document stipulated the Romanian post office's exclusivity when it came to providing this type of services on Romania's territory. See Ibid., 219.

109 Ibid., 228.

110 Ionaşcu, Bărbulescu and Gheorghe 1971, 391-399.

111 The consular convention between Romania and Russia was published in Ibid., 355-367.

112 The Romanian diplomatic agents to Sankt Petersburg were: George C. Filipescu (4 April 1874 - 12 July 1876), Ioan A. Cantacuzino (12 July 1876 - 1 March 1877) and Ioan Gr. Ghica (4 April 1877 - 10 October 1878). Between 1 March and 4 April 1877 the agency did not have a titular due to economic reasons. See Istoria României în date 2003, 896.

113 During this interval, Romania was represented by: Ioan Gr. Ghica (10 October $1878-21$ March 1881), Nicolae Kretzulescu (25 July 1881 - 10 April 1886), Gheorghe M. Ghica (10 April 1886 - 31 January 1889), Emil I. Ghica (31 January 1889 - 17 July 1891), Alexandru C. Catargi (14 November 1892 - 7 October 1895), Gheorghe Rosetti-Solescu (1 December 1895 - 15 August 1911), Constantin C. Nanu (15 October 1911 - 1 October 1913) and Constantin I. Diamandi (1 October 1913 - 13 January 1918). See Ibid., 897.

114 For such an example, see Bezviconi 1947, 426.

174 
In addition to the significant Romanian military contribution during the conflict, these personal ties probably played their part in Russia's prompt recognition of Romania's independence, an event that took place on 15/27 October 1878.115 However, the peace treaty signed at the end of the war gave rise to new dissensions, as the Russian government had territorial claims even from its ally. The three counties comprising the south of Bessarabia, namely Cahul, Bolgrad and Ismail, thus became a part of Russia, but not without protests, while Romania was "indemnified" by taking possession of Dobrudja. 116

The end of 1888 witnessed other complications in the relations between Romania and Russia, after the Romanian government expelled the icon peddlers and veterinary agents of Russian origin. ${ }^{117}$ A sinuous evolution of the connections between the two states was recorded in the last decade of the $19^{\text {th }}$ century as well, in accordance with the moment's political situation. For instance, a part of the tensions that appeared after the Berlin Congress were neutralised by King Carol I's trip to Russia in 1898, an episode that was that much more important as it was the first official visit made by a chief of the Romanian independent state to Russia. 118

The end of World War I brought to the fore major diplomatic problems caused by the situation of the prisoners of war, their number being exceptionally large. For example, it was estimated that in 1920 there existed around 14,000 Romanian prisoners in Russia and their repatriation through the mediation of the Nansen commission ${ }^{119}$ and the International Red Cross would have cost the Romanian government around 70,000 pounds (the total sum actually paid by Romania was 52,584 pounds). ${ }^{120}$ It seems that, at least at first, the Romanian authorities' interest in this matter was very low, as more telegrams from the part of those involved in these actions were necessary in order for the Romanian officials to give a vague reply before

\footnotetext{
115 Istoria României în date 2007, 244.

116 This issue was largely treated by the Romanian historiography and, as a result, I will not give any further details here. For a short presentation of the negotiations' evolution and of the general political context, see Daniela Buşă, Modificări politico-teritoriale în sud-estul Europei între Congresul de la Berlin şi primul război mondial (1878-1914) (Bucharest: Paideia, 2003), 48-60.

117 Calafeteanu and Popişteanu 1986, 145.

118 Ibid., 149.

119 More information about the role played by Fridtjof Nansen in the League of Nations can be found in Florin Hera, "Fridtjof Nansen (1861-1930)," in Diplomați iluştri, Vol. II (Bucharest: Editura Politică, 1970), 386-396.

${ }^{120}$ Ioana Ecaterina Cazacu, "The Nansen Commission and the Romanian prisoners of War's repatriation from the Russian territories," The Romanian Journal for Baltic and Nordic Studies Vol. 3, Issue 1 (2011): 149-150, 158.
} 
ceasing communication altogether. ${ }^{121}$ Only international pressure coming from the secretary-general of the League of Nations succeeded in obtaining a favourable response from Romania, the delays being justified by some alleged misunderstandings. Consequently, between 1920 and 1922, the Nansen Commission, with the support of the International Red Cross, achieved the repatriation of 18,140 Romanians by using the Baltic Sea ports and the railways from the region, of 901 Romanians who left the Russian territory in the Black Sea area and of 649 prisoners of the same nationality who embarked at Vladivostok. ${ }^{122}$ As a result, from the Commission's 427,886 successful repatriations, $19,690^{123}$ concerned Romanian ethnics.

\section{Concluding remarks}

Diplomacy has played and continues to play a crucial part in the relations between different political entities and, in fact, this study was built around this irrefutable statement. I considered that presenting certain aspects of ceremonial and some backstage facets of negotiation from the protagonists' viewpoint could deepen our understanding of the ties between the Romanian area, on the one hand, and the Nordic countries and Russia, on the other hand, during the modern period. Therefore, travel accounts and general context information were combined in an attempt to offer the reader an overall picture of the manner in which the foreign envoys were greeted and treated by the Romanian rulers, but also of the means that the former had at their disposal for showing their appreciation for what they received.

Actually, as it was repeatedly emphasised throughout the study, the display of benevolent attitudes and polite gestures denoted that the rapports between the state which had sent its representatives abroad and the host country were good (or even excellent in some cases) and that the rulers wanted to preserve their quality. As a result, the Nordic (mostly Swedish) and Russian delegates were greeted by a large suite and their stay in the Romanian area was habitually characterised by a sequence of feasts and other pleasant activities prepared especially for them. Moreover, both the rulers and the emissaries paid close attention to the courtesies embedded in the protocol of official meetings, while the exchange of precious gifts usually accompanied these interactions. Interestingly enough, aside from the fact that these general elements were in use at all the European courts and that they remained almost unmodified from the $17^{\text {th }}$ century until the $19^{\text {th }}$

\footnotetext{
121 Ibid., 150-151.

122 Ibid., 156.

123 This number represents the sum of the three figures noted in the text. The number found by the above-cited author in the official reports is 19,188 .
}

176 
century, travellers discovered that the ritual was nearly identical in Moldavia and Wallachia, probably due to the fact that both provinces were vassals of the Ottoman Empire.

But the pomp and entertainments entailed by the passage of such delegations incurred large costs for the transited regions. Hence, providing supplies, accommodation and other facilitations to the deputations seriously affected the inhabitants. A few of the diplomats were well aware of this and tried to relieve some of the pressure (without much success, however). Others, particularly Russia's envoys, affirmed that at least a part of what they received was ceded voluntarily and gladly by the locals, owing to the positive feelings the latter harboured for the Russians. According to the same logic, the Russian Empire only desired to help its fellow Orthodox believers and even fought a number of wars with the Ottomans in order to fulfil this altruistic purpose. Clearly, such allegations were only meant to give a plausible explanation for the Tsars' encroachments in the area and to assuage the Russians' consciousness when faced with the abuses committed against the Romanian people.

Russia's noteworthy interests in South-Eastern Europe occasioned very frequent political, military and diplomatic connections between the Empire and Moldavia and Wallachia. On the other hand, the Nordic countries' remoteness in relation to the Romanians acted as an inhibitor of their mutual contacts. Notwithstanding, a series of rapports between Northern Europe and the Black Sea area existed and their intensity increased during the $1^{\text {th }}$ century, as proven by the establishment of reciprocal consulates, by the official notifications regarding changes in the countries' statuses, by the sovereigns' visits, by the international treaties co-signed by the states had in view or even by some foreign policy similarities between Romania and Sweden during the First World War.

However, irrespective of the differences between the Nordic countries and Russia in their relations with Transylvania, Moldavia or Wallachia, their envoys were treated identically by the Romanian rulers, a fact which demonstrates the undeniable preponderance granted to diplomatic usages and courtesy gestures in the modern period. Thus, all the interactions depicted in detail or merely sketched in the present study attest to diplomacy's relevance during past epochs, but also allow us to intuit the importance it had as a precursor of contemporary commercial, scientific or cultural ties. 


\section{References:}

\section{A. Travel writings:}

Bezviconi, Gheorghe. Călători ruşi în Moldova şi Muntenia. Bucharest: 1947. Cernovodeanu, Paul, ed. Călători străini despre Tările Române în secolul al XIXlea, New Series, Vol. I (1801-1821). Bucharest: Editura Academiei Române, 2004.

Cernovodeanu, Paul and Daniela Buşă eds. Călători străini despre Țările Române în secolul al XIX-lea, New Series, Vol. II (1822-1830). Bucharest: Editura Academiei Române, 2005.

Cernovodeanu, Paul and Daniela Buşă eds. Călători străini despre Țările Române în secolul al XIX-lea, New Series, Vol. III (1831-1840). Bucharest: Editura Academiei Române, 2006.

Cristea, George. Regi şi diplomați suedezi în spațiul românesc (secolele XII-XX). Cluj-Napoca: Academia Română, Centrul de Studii Transilvane, 2007.

Holban, Maria, ed. Călători străini despre T,ările Române, Vol. I. Bucharest: Editura Ştiințifică, 1968.

Holban, Maria, M. M. Alexandrescu-Dersca Bulgaru and Paul Cernovodeanu, eds. Călători străini despre Tările Române, Vol. III. Bucharest: Editura Ştiințifică, 1971.

Holban, Maria, M. M. Alexandrescu-Dersca Bulgaru and Paul Cernovodeanu, eds. Călători străini despre Țările Române, Vol. V. Bucharest: Editura Ştiințifică, 1973.

Holban, Maria, M. M. Alexandrescu-Dersca Bulgaru and Paul Cernovodeanu, eds. Călători străini despre Tările Române, Vol. VIII. Bucharest: Editura Ştiințifică şi Enciclopedică, 1983.

Holban, Maria, M. M. Alexandrescu-Dersca Bulgaru and Paul Cernovodeanu, eds. Călători străini despre Tările Române, Vol. IX. Bucharest: Editura Academiei Române, 1997.

Holban, Maria, Maria M. Alexandrescu-Dersca Bulgaru and Paul Cernovodeanu, eds. Călători străini despre T,ările Române, Vol. X, part I. Bucharest: Editura Academiei Române, 2000.

Holban, Maria, Maria M. Alexandrescu-Dersca Bulgaru and Paul Cernovodeanu, eds. Călători străini despre Țările Române, Vol. X, part II. Bucharest: Editura Academiei Române, 2001.

Iorga, Nicolae. “Carol al XII-lea, Petru cel Mare şi T,ările Noastre (17091714)." Analele Academiei Române. Memoriile Secțiunii Istorice Series II, Tome XXXIII (1910-1911): 71-127.

Iorga, Nicolae. Istoria românilor prin călători. Bucharest: Eminescu, 1981. 
Karadja, Constantin I. "Le journal de Paul Jamjouglou de Constantinople à Hotin en 1746." Revue Historique du Sud-Est Européen (1930): 17-34.

Rosetti, General R. Notele unui ofițer norvegian inaintea şi în timpul Răsboiului de Neatârnare 1876-1878. Bucharest: Cultura Națională, 1928.

\section{B. General and specialised works:}

Boicu, L., V. Cristian and Gh. Platon, eds. România în relațiile internaționale 1699-1939. Jassy: Junimea, 1980.

Buşă, Daniela. Modificări politico-teritoriale în sud-estul Europei între Congresul de la Berlin şi primul război mondial (1878-1914). Bucharest: Paideia, 2003.

Calafeteanu, Ion and Cristian Popişteanu, eds. Politica externă a României: dicționar cronologic. Bucharest: Editura Ştiințifică şi Enciclopedică, 1986.

Djuvara, Neagu. Intre Orient şi Occident. Țările române la începutul epocii moderne (1800-1848). Bucharest: Humanitas, 2005.

Grancea, Mihaela. Călători străini prin Principatele Dunărene, Transilvania şi Banat (1683-1789). Identitate şi alteritate. Sibiu: Editura Universității „Lucian Blaga”, 2002.

Hurdubețiu, Ion. Istoria Suediei. Bucharest: Editura Ştiințifică şi Enciclopedică, 1985.

Ionaşcu, Ion, Petre Bărbulescu and Gheorghe Gheorghe. Relațiile internaționale ale României în documente (1368-1900). Culegere selectivă de tratate, acorduri, convenții şi alte acte cu caracter internațional. Bucharest: Editura Politică, 1971.

Istoria României în date. Elaborated by Dinu C. Giurescu, Horia C. Matei, Nicolae C. Nicolescu, Marcel D. Popa, Gheorghe Rădulescu, Alexandru Stănciulescu, coordinator Dinu C. Giurescu. Bucharest: Editura Enciclopedică, 2003.

Istoria României în date. Elaborated by Dinu C. Giurescu, Horia C. Matei, Nicolae C. Nicolescu, Marcel D. Popa, Gheorghe Rădulescu, Alexandru Stănciulescu, coordinator Dinu C. Giurescu, Second revised and enlarged edition. Bucharest: Editura Enciclopedică, 2007.

\section{Studies and articles:}

Cazacu, Ioana Ecaterina. "The Nansen Commission and the Romanian prisoners of War's repatriation from the Russian territories." The Romanian Journal for Baltic and Nordic Studies Vol. 3, Issue 1 (2011): 145159. 
Clerc, Louis. "The Eye of the Beholder: the Finns, Finland and Paris, 18701940." Valahian Journal of Historical Studies no. 2 (2004): 47-66.

Costea, Ionut,. "Language and Identity: The Nobility of Pre-modern Transylvania." Transylvanian Review Vol. XIII, no. 1 (2004): 69-88.

Cristea, George. "Călători români în Suedia (secolele XVII-XX)." In Bocşan Nicolae and Ioan Bolovan, eds. Călători români în Occident. Secolele XVII-XX. Cluj-Napoca: Institutul Cultural Român, 2004, 159-172.

Hera, Florin. "Fridtjof Nansen (1861-1930)." In Diplomați iluştri, Vol. II. Bucharest: Editura Politică, 1970, 355-397.

Ignat-Coman, Sanda Luminița. "Identitatea națională în opera lui Valeriu Branişte." In Bărbulescu, Constantin, Ioana Bonda, Cecilia Cârja, Ion Cârja and Ana Victoria Sima, eds. Identitate şi alteritate: Studii de istorie politică şi culturală, Vol. 5. Cluj-Napoca: Presa Universitară Clujeană, 2011, 285-293.

Maleon, Bogdan-Petru. "Între slavonismul cultural şi scrisul în limba română: clerul de mir ortodox din Moldova medievală." In Mihalache, Andi and Adrian Cioflâncă, eds. In medias res. Studii de istorie culturală. Jassy: Editura Universității „Al. I. Cuza”, 2007, 331349.

Malița, Mircea. “Diplomatul în istorie. Introducere la o galerie de portrete." In Diplomați iluştri, Vol. I. Bucharest: Editura Politică, 1969, 5-14.

Mehedinți, Mihaela. "Farfurii, tacâmuri şi pahare. Călători nordici şi ruşi despre alimentația românilor (secolele XVIII-XIX)." In Baciu, CrucițaLoredana, Anamaria Macavei and Roxana Dorina Pop, eds. „De la lume adunate..." Lucrările Conferinței Naționale Viață cotidiană, familie, alimentație şi populație in secolele XVIII-XXI. Cluj-Napoca: Presa Universitară Clujeană, 2011, 313-327.

Neagoe, Claudiu. “Veşminte, muzici şi imagini în Țara Românească (secolele XVI-XVIII)." In Mihalache, Andi and Silvia Marin-Barutcieff, eds. De la fictiv la real. Imaginea, imaginarul, imagologia. Jassy: Editura Universității „Alexandru Ioan Cuza”, 2010, 529-541.

Notaker, Henry. “En contrepoint: L'identité nationale à travers les livres de cuisine du XIXe siècle." In Bruegel, Martin and Bruno Laurioux, eds. Histoire et identités alimentaires en Europe. Paris: Hachette Littératures, 2002, 137-150.

Roosen, William. "Early Modern Diplomatic Ceremonial: A Systems Approach." The Journal of Modern History Vol. 52, no. 3 (1980): 452476.

"Speech by H. E. Ambassador of Finland Ms. Irmeli Mustonen on the Occasion of the 90th Anniversary of the Establishment of Diplomatic 
Relations between Finland and Romania." The Romanian Journal for Baltic and Nordic Studies Vol. 3, Issue 1 (2011): 188-189.

"Speech by President of the Romanian Association for Baltic and Nordic Studies Dr. Silviu Miloiu on the Occasion of the 90th Anniversary of the Establishment of Diplomatic Relations between Finland and Romania." The Romanian Journal for Baltic and Nordic Studies Vol. 3, Issue 1 (2011): 190-193.

“State Secretary at the Ministry of Foreign Affairs Bogdan Mazuru's Address on the Occasion of the 90th Anniversary of the Establishment of Diplomatic Relations between Finland and Romania." The Romanian Journal for Baltic and Nordic Studies Vol. 3, Issue 1 (2011): 184-187.

Stroia, Marian. "Rusia şi românii. De la războiul Crimeii la cucerirea independenței. Repere diplomatice (1855-1878)." In Buşă, Daniela and Ileana Căzan, eds. Românii şi geo-politica marilor puteri 1718-1918. Bucharest: Oscar Print, 2009, 54-83.

Topor, Claudiu-Lucian. "German policy and the diplomatic agenda of Romanian neutrality (1914-1916). The prospects for an alliance with Sweden." The Romanian Journal for Baltic and Nordic Studies Vol. 3, Issue 1 (2011): 131-144.

Vares, Vesa. "«Never satisfactory, according to the Finnish standards». From optimism and interest to disappointment and disillusion: Finnish views on the nations in Eastern Central Europe between the world wars." The Romanian Journal for Baltic and Nordic Studies Vol. 3, no. 2 (2011): 225-246. 